\title{
A comparison of the capacity of six cold-pressed plant oils to support development of acquired immune competence in the weanling mouse: superiority of low-linoleic-acid oils
}

\author{
L. M. Hillyer and Bill Woodward* \\ Department of Human Biology and Nutritional Sciences, University of Guelph, Guelph, ON, Canada NIG 2WI
}

(Received 24 May 2001 - Revised 15 February 2002 - Accepted 10 March 2002)

\begin{abstract}
The objective of this investigation was to compare, at several levels of intake, the capacity of diverse cold-pressed plant oils to support development of acquired immune competence assessed in vivo in the weanling mouse. Safflower, maize, soyabean, rapeseed, flaxseed and olive oils were selected to represent widely differing $18: 1 n-9,18: 2 n-6$ and $18: 3 n-3$ contents, and each oil was fed at three dietary levels $(40,80$ and $160 \mathrm{~g} / \mathrm{kg}$ ) as the exclusive source of fat. C57BL/6J mice, ten males and ten females, had free access to each diet for $28 \mathrm{~d}$ beginning at $19 \mathrm{~d}$ of age. The primary serum haemagglutinin response to sheep red blood cells and the primary cutaneous delayed hypersensitivity response to dinitrochlorobenzene were used to assess humoral and cell-mediated competence respectively, on day 28. A zero-time control group, assessed immunologically at $19 \mathrm{~d}$ of age, was also included ( $n$ 32). Independently of dietary oil level, flaxseed, rapeseed, olive and soyabean oils supported development of a more vigorous antibody response than safflower (a useful point of reference, being rich in $18: 2 n-6$ but low in $18: 1 n-9$ and $18: 3 n-3$ ), whereas only flaxseed oil supported development of cell-mediated responsiveness exceeding that of safflower-fed mice. Independently of oil type, development of both immunological indices correlated negatively with intake of $18: 2 n-6$, and development of humoral competence varied inversely with dietary oil level. A low content of $18: 2 n-6$, perhaps less than $20 \mathrm{~g} / 100 \mathrm{~g}$ fatty acids, appears important to the capacity of a plant oil to support development of acquired immune competence in the young.
\end{abstract}

Immune function: Lipids: Linoleic acid

Prediction of the relative immune-supportive capacities of diverse fats and oils is fraught with uncertainty, and a voluminous literature presents a confusing array of conflicting outcomes. Much of the inconsistency among published reports may be attributable to the use of immunological indices, e.g. polyclonal mitogen-induced lymphocyte blastogenesis, that are far removed from antigen-elicited responses in vivo. The results of HosackFowler et al. (1993) attest to this possibility. Moreover, Calder (1998) has pointed out a further problem with in vitro assessment procedures when, as is usually the case, cells are cultured in media containing fetal calf serum rather than autologous serum.

Dietary lipid level is another important variable in studies of fats and immune competence. High levels of dietary fat generally appear immune depressive, at least where cell-mediated immunity is concerned, regardless of fatty acid pattern (Calder, 1998, 2001), and the outcome of comparisons among fat sources may, therefore, depend on the dietary level at which comparison is made. A specific example illustrating this proposition is provided by Hinds \& Sanders (1993). These authors showed that the depressive influence of fish oil relative to blends of olive and safflower oils was apparent, in relation to murine cell-mediated immune competence, only when fish oil comprised more than $50 \%$ of the lipid in a highfat diet. Thus, a single, cohesive investigation comparing diverse fat sources over a broad range of dietary lipid levels is likely to contribute toward an ability to predict differences among fat sources in the capacity to support immune competence.

The focus of attention with regard to the influence of fats and oils on immune competence is on the saturated fatty acids and the $n-3$ and $n-6$ polyunsaturated fatty acids as well as on a presumptive optimal dietary $n-3: n-6$ balance (Robinson \& Field, 1998; Calder, 1998, 2001). In contrast,

Abbreviations: DNCB, dinitrochlorobenzene; SRBC, sheep red blood cell.

* Corresponding author: Dr Bill Woodward, fax +1 519763 5902, email wwoodwar@uoguelph.ca 
information is scant with regard to the immunomodulatory potential of monounsaturated fatty acids, specifically 18 : 1n-9 (Calder, 1998, 2001). Moreover, almost all information pertaining to the influence of dietary $18: 1 n-9$ on indices relating to acquired immune competence derives from studies employing in vitro blastogenesis as the outcome measure (Calder, 1998, 2001). However, one report can be interpreted to suggest that, relative to $20: 5 n-3$ and $22: 6 n-3,18: 1 n-9$ promotes cell-mediated immune competence assessed in vivo (Hinds \& Sanders, 1993). In view of the cardiovascular health-promoting characteristics of 18:1n-9 (Kris-Etherton, 1999), an improved database regarding the immunomodulatory activity of this fatty acid is particularly desirable.

The objective of the present investigation was to use acquired immune responses elicited in vivo as a basis for comparing a spectrum of plant oils selected for diversity in $18: 1 n-9,18: 2 n-6$ and $18: 3 n-3$ content, and fed over a broad range of dietary levels in a single study. The bulk of information relating dietary fats to acquired immune competence pertains to indices of cell-mediated immunity (Calder, 1998, 2001). It was deemed important, therefore, to improve the database regarding the other main type of acquired immune response, namely the humoral (antibody) response, and thereby to conduct an investigation addressing a broader spectrum of indices of acquired immune competence than most previous studies offer. Plant oils were chosen as the focus of attention because these foods are already widely accepted and consumed as health-promoting dietary components. Finally, the investigation centred on the development of acquired immune competence at the weanling stage of life. Consequently, the expectation was that the present study would permit assessment of the predictive value of the fatty acid composition of plant oils vis-à-vis the health-related index of immune competence during the post-weaning development of the immune system.

\section{Materials and methods}

\section{Animals and diets}

Male and female C57BL/6J mice were used from an inhouse breeding colony established in 1989 with mice purchased from the Jackson Laboratory, Bar Harbor, ME, USA. The animals were weaned at $19 \mathrm{~d}$ of age and were immediately randomized, each mouse to receive one of eighteen experimental diets. The mice were caged individually in a windowless room maintained at $25-27^{\circ} \mathrm{C}$ with a photoperiod (fluorescent lighting) of $14 \mathrm{~h}$ light and $10 \mathrm{~h}$ darkness. Experimental purified diets were based on the AIN 93G formulation (Reeves et al. 1993) with modification, as necessary, to accommodate type and level of oil while maintaining a metabolizable energy content (calculated) of $16.6 \mathrm{~kJ} / \mathrm{g}$ diet (Table 1). Each diet was made with one of six sources of cold-pressed oil, namely safflower, maize, soyabean, rapeseed, flaxseed and olive, included at one of three dietary levels (40, 80, or $160 \mathrm{~g} /$ $\mathrm{kg}$ ) and, as dietary oil level increased, the level of cellulose also increased while the level of dietary maize starch decreased (Table 1). Maize oil (Spectrum Naturals
Table 1. Composition of purified diets ( $\mathrm{g} / \mathrm{kg}$ diet)

\begin{tabular}{|c|c|c|c|}
\hline \multirow[b]{2}{*}{ Ingredient } & \multicolumn{3}{|c|}{ Dietary oil level (g/kg) } \\
\hline & 40 & 80 & 160 \\
\hline Casein* ${ }^{*}$ & 200 & 200 & 200 \\
\hline Maize starch $\ddagger$ & 457.5 & 377.5 & 217.5 \\
\hline Dextrin* & 132 & 132 & 132 \\
\hline Sucrose§ & 100 & 100 & 100 \\
\hline Cellulose* $\|$ & 20 & 60 & 140 \\
\hline Micronutrient premix & 45 & 45 & 45 \\
\hline L-Cystine & 3 & 3 & 3 \\
\hline Choline bitartrate & 2.5 & 2.5 & 2.5 \\
\hline tert-Butylhydroquinone & 0.014 & 0.014 & 0.014 \\
\hline Oil $^{\star *}$ & 40 & 80 & 160 \\
\hline
\end{tabular}

*United States Biochemical Corp., Cleveland, OH, USA.

† Vitamin-free.

$¥$ St Lawrence Starch Co, Mississauga, ON, Canada.

§ICN Biomedicals Inc., Aurora, OH, USA.

|| Celufil, non-nutritive bulk.

I Reeves et al. (1993).

${ }^{\star *}$ Fresh-pressed: safflower, soyabean, rapeseed, flaxseed and olive oils (Omega Nutrition Canda, Inc., Vancouver, BC, Canada); maize oil (The Big Carrot Health Food Market, Toronto, ON, Canada).

unrefined pure pressed) was purchased from The Big Carrot Health Food Market (Toronto, ON, Canada), whereas the other five oils (Omegaflo ${ }^{\circledR}$ ) were the generous gift of Omega Nutrition Canada, Inc. (Vancouver, BC, Canada). The fatty acid composition expected of the oils used in this investigation (Shukla, 1994; Bhatty, 1995) was confirmed by chemical analysis, and the results pertaining to the three fatty acids of primary interest to this work are summarized in Table 2. Vitamin-free casein was used as the $\mathrm{N}$ source because the ethanolic extraction process to which this product has been subjected minimizes its fatty acid content. Thus, the diets differed only with regard to the source and/or level of oil, and proximate analysis revealed a DM content of 958 (SD 11) g/kg, a crude protein $(\mathrm{N} \times 6.25)$ content of $183(\mathrm{SD} 11) \mathrm{g} / \mathrm{kg}$ and a lipid content of 46 (SD 2), 82 (SD 3) or 159 (SD 3) g/kg, on an as-fed basis. The mice had free access to diet and tap water throughout the experimental period, and coprophagy was permitted. Animal care and experimental usage were conducted according to the current guidelines of the Canadian Council on Animal Care.

\section{Experimental design}

Each diet was provided to ten male and ten female animals

Table 2. Fatty acid composition of dietary oils: oleic, linoleic and $\alpha$-linolenic acids

\begin{tabular}{lccc}
\hline & \multicolumn{3}{c}{ Fatty acid content $(\mathrm{g} / 100 \mathrm{~g}$ total fat) } \\
\cline { 2 - 4 } Oil source & $18: 1 n-9$ & $18: 2 n-6$ & $18: 3 n-3$ \\
\hline Safflower & 22.5 & 61.4 & $\mathrm{ND}$ \\
Maize & 33.3 & 48.0 & 0.4 \\
Soyabean & 27.9 & 32.9 & $5 \cdot 7$ \\
Rapeseed & 46.9 & 18.1 & $9 \cdot 1$ \\
Flax & $23 \cdot 8$ & 13.8 & 43.5 \\
Olive & 50.3 & 20.7 & 0.7 \\
\hline
\end{tabular}

ND, not detected. 
for $28 \mathrm{~d}$, i.e. from the weanling stage of life (19d of age) through adolescence ( $47 \mathrm{~d}$ of age), and both cell-mediated and humoral immune competence was assessed in each animal at the end of the experimental period. In addition, a zero-time control group was included (sixteen males and sixteen females), and each of these animals was assessed immunologically at $19 \mathrm{~d}$ of age. Further, unimmunized negative controls were included with each dietary group (two males and two females) and also with the zero-time control group (three animals of each gender).

\section{Blood sampling and serum storage}

A blood sample was taken from each mouse at the end of the experimental period, i.e. either at $47 \mathrm{~d}$ of age or (for the zero-time control group) at $19 \mathrm{~d}$ of age. For this purpose, animals were anaesthetized with $\mathrm{CO}_{2}$ as described elsewhere (Shipp \& Woodward, 1998), and blood was taken from the orbital plexus. The blood was allowed to clot at room temperature for approximately $1 \mathrm{~h}$, and the resulting serum was stored at $-80^{\circ} \mathrm{C}$ for up to 6 months awaiting analysis.

\section{Fatty acid analyses of serum and dietary oils}

Extraction, methylation and GC analysis of serum samples and of the six oils used to formulate the experimental diets were conducted as described by Holub \& Skeaff (1987). A Hewlett Packard 6890A GLC was used, and the instrument was fitted with a $30 \mathrm{~m} \times 0.53 \mathrm{~mm}$ internal diameter $\mathrm{DB}^{\circledR}$ 225 (50\% cyanopropylphenyl methylpolysiloxane) J\&W Scientific megabore fused-silica capillary column (Chromatographic Specialties, Inc., Brockville, ON, Canada), a flame ionization detector and a 3396A series integrator. Gas flow rates through the detector were maintained at 360,36 and $31 \mathrm{ml} / \mathrm{min}$ for air, $\mathrm{H}_{2}$ and $\mathrm{N}_{2}$ respectively. The column oven temperature was $205^{\circ} \mathrm{C}$, whereas the detector and injector were maintained at $250^{\circ} \mathrm{C}$.

\section{Compositional analyses of diets and carcasses}

Diets and animal carcasses were stored at $-20^{\circ} \mathrm{C}$ while awaiting compositional analysis. The determination of DM, crude protein $(\mathrm{N} \times 6.25)$ and lipid contents is described elsewhere (Woods \& Woodward, 1991).

\section{Assessment of cell-mediated immune competence}

Cell-mediated immune competence was assessed as the primary delayed cutaneous hypersensitivity response to dinitrochlorobenzene (DNCB) according to a modification of a procedure described by Corsini et al. (1979). Briefly, animals were sensitized by application of $50 \mu \mathrm{l} 50 \mathrm{~mm}$ DNCB in acetone to the shaved abdominal skin on days 22 and 23 of the experimental feeding period, or on days 13 and 14 of postnatal life in the case of the zero-time control group. Four days after the second sensitizing dose, i.e. day 27 of the experimental feeding period or day 18 of postnatal life for the zero-time controls, each mouse was challenged with $25 \mu \mathrm{l} 25 \mathrm{~mm}$ DNCB in acetone divided between the two sides of the right external ear. The left pinna of each mouse was treated similarly with $25 \mu \mathrm{l}$ acetone. The anti-DNCB response was assessed by determining the accumulation of water (i.e. inflammatory fluid) in the right external ear $24 \mathrm{~h}$ after challenge. To accomplish this, the \% moisture was determined gravimetrically in each pinna by drying the tissue overnight in a vacuum oven set at $80^{\circ} \mathrm{C}$. The inflammatory response of each mouse was expressed as the difference in \% moisture between the right (challenged) and left external ears. Unimmunized negative controls were treated and assessed in exactly the same manner as immunized animals, except that they received $50 \mu \mathrm{l}$ acetone only, applied to the shaved abdominal skin.

\section{Assessment of humoral immune competence}

Humoral immune competence was assessed as the primary antibody response to the sheep red blood cell (SRBC) according to a procedure described elsewhere (Woodward et al. 1995). Briefly, each mouse received a sensitizing intraperitoneal injection of $4 \times 10^{8}$ washed SRBC (CedarLane, Hornby, ON, Canada) in $0.1 \mathrm{ml}$ physiological saline (M.T.C. Pharmaceuticals, Cambridge, ON, Canada) on day 23 of the experimental period, or on day 14 of postnatal life in the case of the zero-time control group. Unimmunized negative controls received only an intraperitoneal injection of $0.1 \mathrm{ml}$ physiological saline. Five days later, blood was taken from the orbital sinus, and the serum was frozen at $-80^{\circ} \mathrm{C}$ to await assay. The antiSRBC agglutinin titre (concentration) of each serum sample was assessed by means of a series of twofold dilutions in which SRBC from the immunizing lot were suspended. Consequently, titre was determined as the inverse base 2 logarithm of the maximum serum dilution at which agglutination of SRBC was discernible with the unaided eye. By this procedure, the lowest discernible titre was two, corresponding to a serum dilution of $1: 3$, and any sample in which agglutination of SRBC was indiscernible at this dilution was assigned a titre of zero. Titres were determined by an observer (B.W.), who was blinded to the dietary treatment code.

\section{Statistical analyses}

Statistical analysis was performed according to the SAS Guide (1985; SAS Institute Inc., Cary, NC, USA). The predetermined upper limit of probability for statistical significance thoughout this investigation was $P=0.05$, and means comparisons were two-tailed. All data sets, with the zero-time control group excluded, were first subjected to two-way ANOVA, main effects being dietary oil level and type. Where justified by the statistical probability (i.e. $P \leq 0.05$ ), means comparisons within main effects were made using Tukey's Studentized Range procedure. In addition, where comparisons with the zero-time control group were desired, data were combined across oil levels within each plant oil type to permit analysis by one-way ANOVA followed, if justified by the resulting statistical probability (i.e. $P \leq 0.05$ ), by Tukey's Studentized Range procedure. Data that were not normally distributed, and that could not be normalized by either logarithmic or 
square-root transformation, were analysed by the KruskalWallis test ( $\chi^{2}$ approximation) applied to Wilcoxon rank sums. Where warranted by the resulting statistical probability value (i.e. $P \leq 0.05$ ), this procedure was followed by $\chi^{2}$ comparisons of Wilcoxon two-sample rank sums. For some purposes, correlational analysis was conducted, again only after ensuring that data sets met the requirements for parametric testing.

\section{Results}

In the present investigation, data from males and females were kept separately. Except for the indices of final body weight and food intake, however, no gender-related effects were seen (results not shown). All diets supported good rates of weight gain, and neither final body weight nor food intake was influenced by the type of dietary oil (Table $3, P=0.30$ and 0.06 respectively). In contrast, dietary oil level influenced both food intake and final body weight (Table 3, $P=0.0001$ and 0.02 respectively) independently of oil type (Table 3, interaction term $P=0.08$ and 0.95 repectively). In this regard, food intake decreased modestly and progressively as dietary fat level increased from 40 to $160 \mathrm{~g} / \mathrm{kg}$, whereas body weight, although affected by dietary lipid content, exhibited no clear trend in relation to this index. Appropriately, the mice gained both fat and lean tissue during development from weaning through adolescence. During this period, carcass fat levels increased, and consequently DM levels also increased (Table 3, $P=0.0001$ for both indices), whereas the proportion of carcass protein was unaffected by age (Table 3,
$P=0 \cdot 90)$. Neither type nor level of dietary oil influenced the distribution of weight gain between fat and lean tissue. A statistically significant influence of dietary oil level was apparent on carcass DM content (Table 3, $P=0.007$ ), but no clear dose-response relationship emerged in this regard.

The serum fatty acid profiles of mice fed the various diets reflected the composition of the oil consumed with regard to $n-3$ and $n-6$ fatty acids and 18: $n-9$ (Table 4, $P=0.0001)$ Therefore, the serum analyses independently confirmed the consumption of diets containing fat sources differing in composition with regard to the fatty acids of interest to the present investigation. Dietary oil type also influenced serum total fatty acid concentration, although not in a manner that related clearly to the $n-3, n-6$ or 18 : $1 n-9$ content of the oil (not shown, $P=0 \cdot 0002$ ). This influence on serum total fatty acid concentration was independent of oil level (two-way ANOVA, $P=0 \cdot 20$ for interaction term), a main effect that exerted no effect on the total fatty acid concentration of the serum $(P=0 \cdot 12$, results not shown). Nevertheless, dietary oil level affected the serum fatty acid profile. Thus, animals fed diets containing $40 \mathrm{~g}$ fat $/ \mathrm{kg}$ exhibited lower serum concentrations of total $n-6$ fatty acids and of $20: 4 n-6$ than animals fed the two higher levels of dietary fat (means and main-effect $P$ value in two-way ANOVA respectively: $714 v .882$ and $935 \mu \mathrm{g} / \mathrm{ml}, P=0.0001$ and 158 v. 186 and $191 \mu \mathrm{g} / \mathrm{ml}$, $P=0.002$; in both cases $P \leq 0.05$ according to two-tailed application of Tukey's Studentized Range procedure). These effects were independent of oil type as indicated by the interaction terms in the two-way ANOVA that

Table 3. Growth indices of mice fed from weaning ( $19 \mathrm{~d}$ postpartum) to 7 weeks of age, and of the zero-time control group examined at weaning $(19 \mathrm{~d} \text { of age })^{*}$

(Mean values)

\begin{tabular}{|c|c|c|c|c|c|c|}
\hline \multirow[b]{2}{*}{ Group } & \multirow[b]{2}{*}{$n$} & \multirow{2}{*}{$\begin{array}{c}\text { Body weight at } \\
7 \text { weeks of age } \\
\text { (g/mouse) } \dagger\end{array}$} & \multicolumn{3}{|c|}{ Carcass composition (g/kg wet wt) ${ }^{\ddagger \S}$} & \multirow{2}{*}{$\begin{array}{c}\text { Food intake } \\
(\mathrm{g} / \text { mouse per } \mathrm{d}) \|\end{array}$} \\
\hline & & & DM & Fat & Protein & \\
\hline \multicolumn{7}{|c|}{ Main effect: dietary oil type } \\
\hline Zero-time & 32 & - & $296^{\mathrm{b}}$ & $89^{\mathrm{b}}$ & 150 & - \\
\hline Safflower & 20 & 21.5 & $360^{\mathrm{a}}$ & $141^{\mathrm{a}}$ & 157 & 3.5 \\
\hline Maize & 20 & $22 \cdot 0$ & $367^{\mathrm{a}}$ & $140^{\mathrm{a}}$ & 153 & 3.5 \\
\hline Soyabean & 20 & $22 \cdot 1$ & $373^{\mathrm{a}}$ & $142^{\mathrm{a}}$ & 162 & 3.5 \\
\hline Rapeseed & 20 & $22 \cdot 4$ & $368^{\mathrm{a}}$ & $144^{\mathrm{a}}$ & 157 & $3 \cdot 4$ \\
\hline Flax & 20 & $22 \cdot 2$ & $374^{\mathrm{a}}$ & $142^{\mathrm{a}}$ & 160 & 3.4 \\
\hline Olive & 20 & $21 \cdot 7$ & $365^{a}$ & $146^{\mathrm{a}}$ & 156 & 3.3 \\
\hline Pooled SEM & & 0.014 & $6 \cdot 25$ & 3.90 & 3.55 & 0.016 \\
\hline \multicolumn{7}{|c|}{ Main effect: dietary oil level ( $\mathrm{g} / \mathrm{kg}$ diet as fed) } \\
\hline $40 \mathrm{~g} / \mathrm{kg}$ diet & 60 & $22 \cdot 0^{\mathrm{ab}}$ & $367^{\mathrm{ab}}$ & 144 & 157 & $3 \cdot 6^{\mathrm{a}}$ \\
\hline $80 \mathrm{~g} / \mathrm{kg}$ diet & 60 & $22 \cdot 4^{\mathrm{a}}$ & $376^{a}$ & 146 & 160 & $3 \cdot 4^{b}$ \\
\hline $160 \mathrm{~g} / \mathrm{kg}$ diet & 60 & $21 \cdot 6^{\mathrm{b}}$ & $361^{\mathrm{b}}$ & 138 & 156 & $3 \cdot 3^{c}$ \\
\hline Pooled SEM & & 0.010 & - & - & - & 0.011 \\
\hline
\end{tabular}

${ }^{*}$ For details of diets and procedures, see Tables 1 and 2 and p. 172.

a,b,c, Mean values within each main effect and column with unlike superscript letters were significantly different (Tukey's Studentized Range test two-tailed, $P \leq 0.05$ ).

†Body weight after 4-week feeding period. Two-way ANOVA, $P=0.3032$ (oil type), 0.0179 (oil level) and 0.9490 (interaction). Mean values are antilogs of logtransformed values. Initial body weights of all groups and weight of the zero-time control group ranged from 8.7 to $9.0 \mathrm{~g} / \mathrm{mouse}$, and did not differ among groups according to the Kruskal-Wallis procedure $(P=0.8655)$.

¥One-way ANOVA comparing oil types (independently of dietary oil level) and including zero-time control: $P=0.0001,0.0001$ and 0.9004 for DM, fat and crude protein $(N \times 6 \cdot 25)$ respectively.

$\S$ Kruskal-Wallis rank sums for influence of oil level (40, 80, $160 \mathrm{~g} / \mathrm{kg}$ respectively): 21530, 24164 and 19286 (DM, $P=0.0067) ; 21859.5,22289$ and 20112.5 (fat, $P=0.2676) ; 20527,22494.5$ and 21958.5 (crude protein $(\mathrm{N} \times 6.25), P=0.3355)$.

$\|$ Two-way ANOVA: $P=0.0644$ (oil type), 0.0001 (oil level) and 0.0807 (interaction). Mean values are antilogs of log-transformed values. 
Table 4. Serum fatty acid composition of mice fed diets differing in oil source*

(Mean values)

\begin{tabular}{|c|c|c|c|c|c|c|c|c|c|}
\hline \multirow[b]{2}{*}{ Dietary group } & \multirow[b]{2}{*}{$n$} & \multicolumn{8}{|c|}{ Fatty acid concentration $(\mu \mathrm{g} / \mathrm{ml})$} \\
\hline & & $18: 1 n-9 \dagger$ & $n-6 \ddagger$ & $18: 2 n-6 \S$ & $20: 4 n-6 \|$ & $n-39$ & $18: 3 n-3^{\star *}$ & 20:5n-3†† & $22: 6 n-3 \neq \ddagger$ \\
\hline \multicolumn{10}{|c|}{ Main effect: dietary oil type } \\
\hline Safflower & 20 & $290^{d}$ & $1084^{\mathrm{a}}$ & $713^{a}$ & $306^{a}$ & $20^{e}$ & $0^{e}$ & $0^{d}$ & $16^{\mathrm{c}}$ \\
\hline Maize & 20 & $458^{\mathrm{b}}$ & $1121^{\mathrm{a}}$ & $742^{\mathrm{a}}$ & $324^{a}$ & $44^{\mathrm{d}}$ & $4^{\mathrm{d}}$ & $0^{d}$ & $35^{\mathrm{b}}$ \\
\hline Soyabean & 20 & $395^{\mathrm{bc}}$ & $1070^{\mathrm{a}}$ & $806^{a}$ & $227^{\mathrm{b}}$ & $133^{\mathrm{c}}$ & $40^{\mathrm{C}}$ & $17^{\mathrm{C}}$ & $75^{\mathrm{a}}$ \\
\hline Rapeseed & 20 & $666^{a}$ & $691^{\mathrm{b}}$ & $532^{\mathrm{b}}$ & $130^{\mathrm{c}}$ & $194^{\mathrm{b}}$ & $57^{\mathrm{b}}$ & $48^{\mathrm{b}}$ & $90^{\mathrm{a}}$ \\
\hline Flax & 20 & $328^{\mathrm{cd}}$ & $448^{\mathrm{C}}$ & $403^{\mathrm{C}}$ & $43^{d}$ & $473^{\mathrm{a}}$ & $251^{a}$ & $169^{\mathrm{a}}$ & $84^{\mathrm{a}}$ \\
\hline Olive & 20 & $653^{\mathrm{a}}$ & $740^{\mathrm{b}}$ & $465^{\mathrm{bc}}$ & $241^{\mathrm{b}}$ & $41^{d}$ & $2^{d}$ & $0^{d}$ & $37^{\mathrm{b}}$ \\
\hline Pooled SEM & & 0.05 & 0.68 & 28.79 & 0.06 & 0.03 & - & - & 0.03 \\
\hline \multicolumn{10}{|c|}{ Main effect: dietary oil level ( $\mathrm{g} / \mathrm{kg}$ diet as fed) } \\
\hline $40 \mathrm{~g} / \mathrm{kg}$ diet & 60 & $550^{a}$ & $714^{\mathrm{b}}$ & $488^{c}$ & $158^{\mathrm{b}}$ & $102^{b}$ & 41 & 36 & 54 \\
\hline $80 \mathrm{~g} / \mathrm{kg}$ diet & 60 & $455^{\mathrm{b}}$ & $882^{\mathrm{a}}$ & $635^{\mathrm{b}}$ & $186^{a}$ & $114^{\mathrm{ab}}$ & 57 & 38 & 55 \\
\hline $160 \mathrm{~g} / \mathrm{kg}$ diet & 60 & $345^{\mathrm{c}}$ & $935^{\mathrm{a}}$ & $711^{\mathrm{a}}$ & $191^{\mathrm{a}}$ & $123^{\mathrm{a}}$ & 78 & 41 & 51 \\
\hline Pooled SEM & & 0.04 & 0.48 & 20.35 & 0.04 & 0.02 & - & - & 0.02 \\
\hline
\end{tabular}

${ }^{*}$ For details of diets and procedures, see Tables 1 and 2 and p. 172

a,b,c,d,e Mean values within each main effect and column with unlike superscript letters were significantly different by two-tailed Tukey's Studentized Range test unless another statistical test is indicated, $(P \leq 0.05)$.

†Two-way ANOVA, $P=0.0001$ (each main effect and the interaction term). Means are antilogs of log-transformed data.

$\ddagger$ Two-way ANOVA, $P=0.0001$ (oil type main effect), $P=0.0001$ (oil level main effect), $P=0.1918$ (interaction). Mean values are squares of square root transformed data.

$\S$ Two-way ANOVA, $P=0.0001$ (each main effect), $P=0.2059$ (interaction).

II Two-way ANOVA, $P=0.0001$ (oil type main effect), $P=0.0019$ (oil level main effect), $P=0.3615$ (interaction). Mean values are antilogs of log-transformed data.

If Total $n$-3: two-way ANOVA, $P=0.0001$ (oil type main effect), $P=0.0150$ (oil level main effect), $P=0.0286$ (interaction). Mean values are squares of square root transformed data.

${ }^{* *}$ Kruskal-Wallis test of Wilcoxon rank sums which, for the oil type main effect $(P=0.0001)$, were 4819 (safflower), 6418 (maize), 13601 (soyabean), 15119 (rapeseed), 19453 (flax) and 5569 (olive), and for the oil level main effect $(P=0.3554)$ were $20602.5(40 \mathrm{~g} / \mathrm{kg}), 21799.5(80 \mathrm{~g} / \mathrm{kg}) \mathrm{and} 22578(160 \mathrm{~g} / \mathrm{kg})$.

†† Kruskal-Wallis test of Wilcoxon rank sums which, for oil type main effect ( $P=0.0001)$, were 5795 (safflower), 5700 (maize), 12354.5 (soyabean), 15971.5 (rapeseed), 19459 (flax) and 5700 (olive), and for oil level main effect $(P=0.7523$ were $21234.5(40 \mathrm{~g} / \mathrm{kg}), 21576.5(80 \mathrm{~g} / \mathrm{kg}) \mathrm{and} 22169(160 \mathrm{~g} / \mathrm{kg})$.

拉 Two-way ANOVA, $P=0.0001$ (oil type main effect), $P=0.6243$ (oil level main effect), $P=0.7358$ (interaction). Mean values are antilogs of log transformed data.

yielded statistical significance levels of $P=0 \cdot 19$ (total $n-6$ fatty acids) and $P=0 \cdot 36(20: 4 n-6)$. Likewise, mice fed diets containing $40 \mathrm{~g}$ fat $/ \mathrm{kg}$ exhibited lower serum total $n-3$ fatty acid concentrations than animals fed diets containing $160 \mathrm{~g}$ fat $/ \mathrm{kg}$, whereas the $80 \mathrm{~g} / \mathrm{kg}$ group did not differ from the other two in terms of this index (mean values $3.1,3.2$ and $3.4 \mu \mathrm{g} / \mathrm{ml}$ in the 40,80 and $160 \mathrm{~g} / \mathrm{kg}$ groups respectively; $P=0.02$ in two-way ANOVA and means compared at $P \leq 0.05$ by two-tailed application of Tukey's Studentized Range procedure). In contrast, serum 18:1n-9 concentration differed among animals fed the three levels of dietary oil, varying inversely with dietary oil level (mean values 550, 455 and $345 \mu \mathrm{g} / \mathrm{ml}$ at 40 , 80 and $160 \mathrm{~g}$ dietary oil $/ \mathrm{kg}$ respectively; $P=0.0001$ in two-way ANOVA, and means compared at $P \leq 0.05$ by two-tailed application of Tukey's Studentized Range procedure). The influence of oil level on the serum concentration of $n-3$ fatty acids and $18: 1 n-9$ depended on the type of dietary oil as indicated by the significance levels of the oil type $\times$ level interaction terms $(P=0.03$ and $0 \cdot 0001$ respectively).

Fig. 1(A) and (B) show the results of the comparison among plant oils as to their ability, independently of dietary oil level, to support development of the primary anti-SRBC antibody response and the primary cellmediated anti-DNCB response. The response exhibited by unsensitized negative controls at $47 \mathrm{~d}$ of age did not differ among dietary groups, and was subtracted from the results of each mouse to produce the results shown. At this age, unsensitized animals exhibited an inflammatory response to DNCB challenge of 3.0 (SD 1.1) \% ( $n$ 72), and failed to exhibit a detectable anti-SRBC titre. Likewise, at $19 \mathrm{~d}$ of age, unsensitized animals exhibited no anti-SRBC titre but produced an inflammatory response to DNCB challenge of 1.3 (SD 1.5) \% ( $n$ 6), and these results were used in calculating the outcome presented for the zero-time control group. Both the cell-mediated response to DNCB and the anti-SRBC antibody titre of the groups of mice fed the various plant oils exceeded the corresponding immune responses of the zero-time controls (Fig. 1(A) and (B)). Groups fed safflower or maize oils did not differ in terms of the acquired immune responses assessed (Fig. 1(A) and (B)). However, these groups of mice exhibited a lower primary anti-SRBC antibody response than the groups fed the other four oils which, in turn, did not differ in this respect (Fig. 1(A)). In contrast, mice fed safflower or maize oil did not differ from the groups fed soyabean, rapeseed, or olive oil in terms of the primary anti-DNCB response, whereas the groups fed flaxseed oil exhibited a greater anti-DNCB response than those fed safflower, maize, or soyabean oils, but did not differ in this respect from the groups fed rapeseed or olive oils (Fig. 1(B)).

It was also of interest to determine the influence of dietary oil level on the immune response indices, and this was tested by means of a two-way ANOVA applied to the data set excluding the zero-time control group. This analysis revealed that the anti-SRBC antibody response (titre) was influenced by dietary oil level (Fig. 2(A), $P=0.002$ ) independently of oil type (interaction term $P=0 \cdot 194$ ), while 
(A)

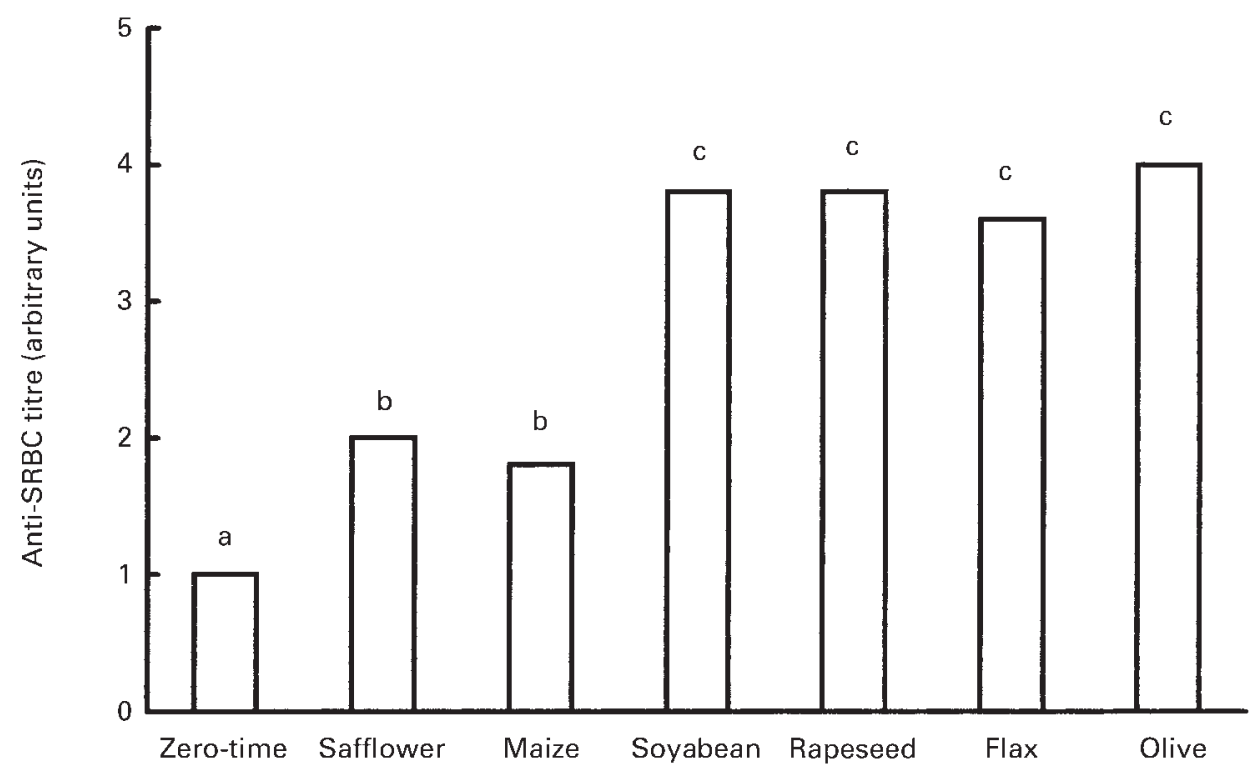

(B)

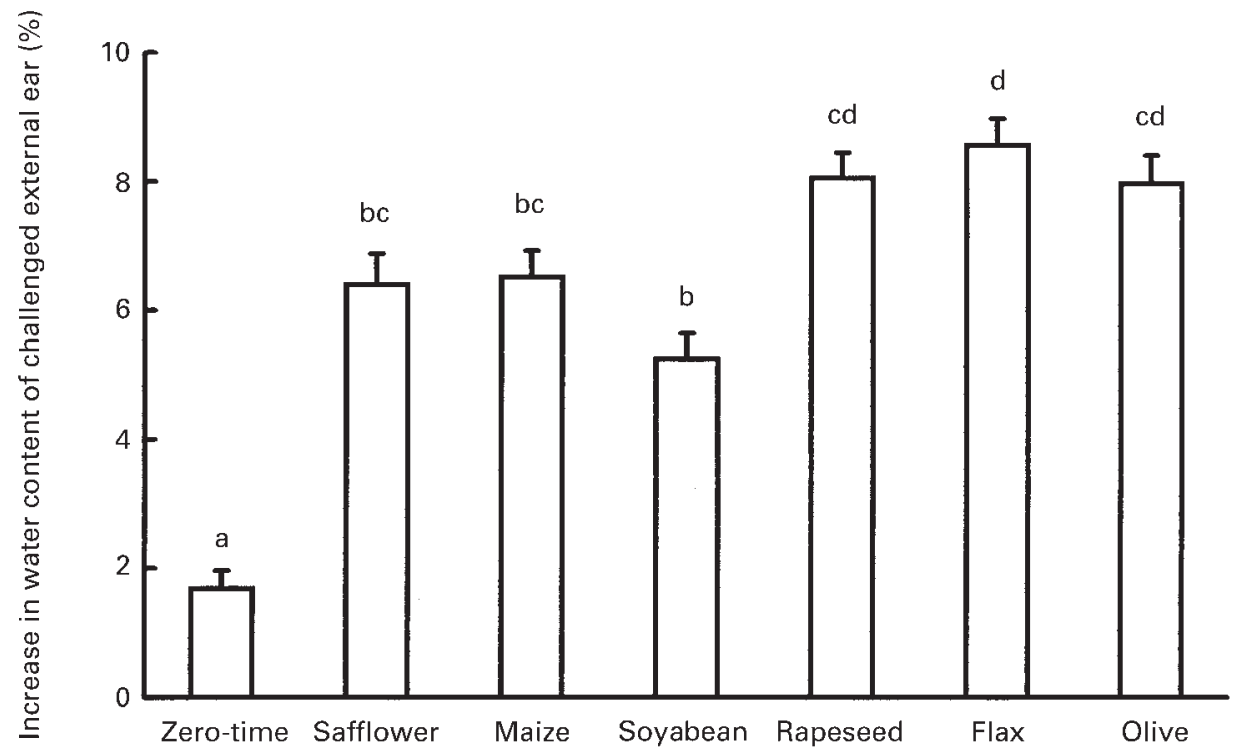

Fig. 1. Primary antibody response to sheep red blood cells (SRBC) and primary cell-mediated response to dinitrochlorobenzene (DNCB) by mice fed purified diets formulated with one of six cold-pressed plant oils. Each oil was fed at three different dietary levels, namely 40,80 and $160 \mathrm{~g} / \mathrm{kg}$ diet as fed, but the data were combined across oil levels to permit comparison both among oil types and with a zero-time control group. Animals were fed from 19 through $47 \mathrm{~d}$ of age (sixty per dietary oil type, i.e. twenty per oil type at each dietary oil level studied), or were examined at $19 \mathrm{~d}$ of age (zero-time control, $n$ 32). Each mouse was sensitized with both SRBC and DNCB. For details of diets and procedures, see Tables 1 and 2 and p. 172. Values are means with standard deviations shown by vertical bars in the case of results pertaining to the antiDNCB response. ${ }^{a, b, c, d}$ Mean values with unlike superscript letters were significantly different $(P \leq 0.05)$. (A), anti-SRBC antibody titre data were analysed by the Kruskal-Wallis procedure $(P=0.0001$, rank sums: $2930,6645,7111,9310,9626,8205.5$ and 9147 for the zero-time control, safflower, maize, soyabean, rapeseed, flaxseed and olive oil groups respectively) followed by $\chi^{2}$ comparisons of Wilcoxon two-sample rank sums. The zero-time control group exhibited a mean titre of $5 \cdot 8$, but is assigned a value of unity for the purpose of graphical comparison. Unsensitized animals exhibited no detectable anti-SRBC titre. (B), data pertaining to the anti-DNCB response were subjected to one-way ANOVA $(P=0.0001$, pooled SEM 0.429) followed by two-tailed application of Tukey's Studentized Range procedure. The response of unsensitized mice to DNCB challenge ( 3.0 and $1.3 \%$ for $47 \mathrm{~d}$ old mice and zero-time controls respectively) has been subtracted from each animal to produce the results shown.

confirming the influence of oil type on this immunological index $(P=0.0002)$. In turn, two-tailed application of Tukey's Studentized Range test $(P \leq 0.05)$ showed that, as a group, the diets containing $40 \mathrm{~g}$ oil $/ \mathrm{kg}$ supported a more vigorous primary antibody response than the diets containing $160 \mathrm{~g}$ oil $/ \mathrm{kg}$, whereas groups fed $80 \mathrm{~g}$ oil $/ \mathrm{kg}$ did not differ from the groups fed either the lower or the higher oil concentrations. In contrast, dietary oil level 
(A)

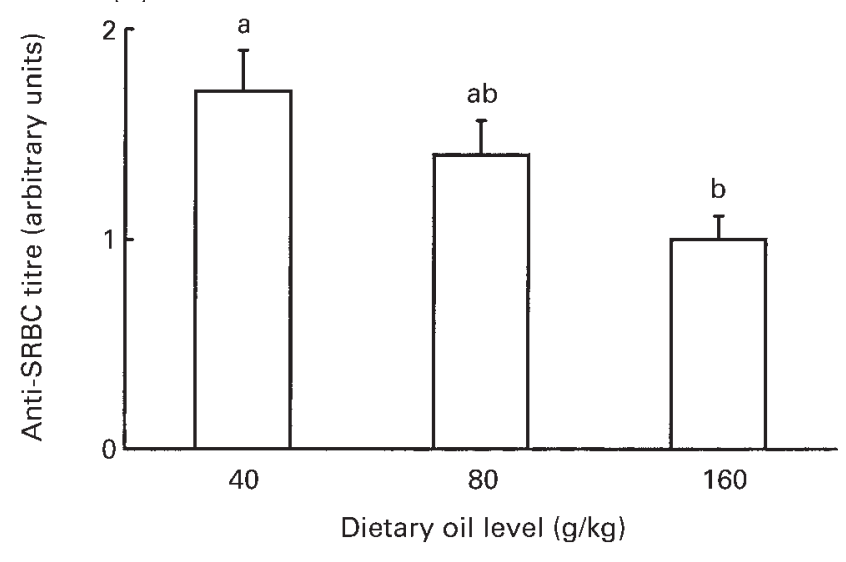

(B)

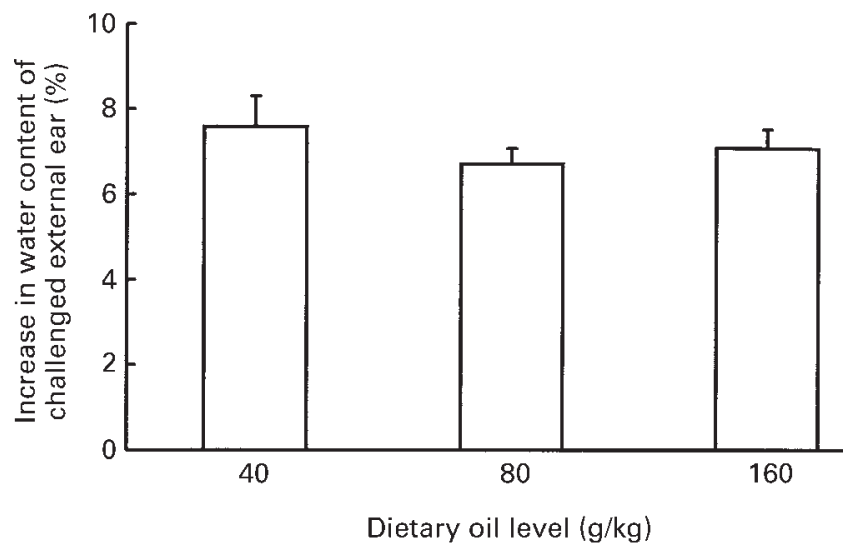

Fig. 2. Primary antibody response to sheep red blood cells (SRBC) and primary cell-mediated response to dinitrochlorobenzene (DNCB) by mice fed purified diets formulated to contain fat at a level of $40,80,160 \mathrm{~g} / \mathrm{kg}$ as fed. At each dietary fat level, six diets were formulated, each with one of six cold-pressed plant oils. For details of diets see Tables 1 and 2 on p. 172. Data were subjected to two-way ANOVA with oil level and oil type as main effects, and the results are shown to permit comparison among dietary oil levels. Animals were fed from 19 through $47 \mathrm{~d}$ of age (120 per dietary oil level, i.e. twenty per oil type at each oil level studied). Each mouse was sensitized with SRBC and DNCB. For details of procedures, see p. 173. Values are means with standard deviations shown by vertical bars. ${ }^{a, b}$ Mean values with unlike superscript letters were significantly different (two-tailed Tukey's Studentized Range test $P \leq 0.05)$. (A), for the anti-SRBC antibody data, pooled SEM 1.58 and $P=0.0023$ (oil level main effect), 0.0002 (oil type main effect) and 0.1940 (interaction). (B), for the anti-DNCB response data, pooled SEM 0.30 and $P=0.1254$ (oil level main effect), 0.0001 (oil type main effect) and 0.2003 (interaction).

exerted no influence on the anti-DNCB response (Fig. 2(B), $P=0 \cdot 125)$, although the analysis confirmed the effect of oil type on this index of cell-mediated immune competence $(P=0.0001)$ and showed that this phenomenon did not depend on oil level (interaction term $P=0 \cdot 200$ ).

Correlation analysis was applied in an attempt to relate the fatty acid composition of the dietary oil to the magnitude of the anti-DNCB and anti-SRBC responses (Table 5). The analysis was conducted across oil sources, but without regard to dietary oil level because this variable exerted little influence on the measures of immune competence used in this investigation. The 18:1n-9 level of the dietary oil did not correlate with either measure of immune response, but a positive correlation was apparent with both immunological indices when the dietary concentration ratio of $18: 1 n-9$ (numerator) and 18:2n-6 (denominator) was examined. The dietary level of $18: 3 n-3$ correlated positively with the anti-DNCB response, but did not correlate with the anti-SRBC response, and the same outcome was apparent both in relation to the concentration ratio of 18:3n-3 (numerator) and 18:2n-6 (denominator) and in relation to the concentration ratio obtained by summing $18: 1 n-9$ plus $18: 3 n-3$ as numerator $v$. $18: 2 n-6$ as denominator. Finally, a negative correlation was found between the dietary level of 18:2n-6 and each of the two immune response indices measured.

\section{Discussion}

The present investigation covers the two types of acquired immune response, namely cell-mediated and humoral. All six plant oils supported development of acquired immune competence to a level exceeding that exhibited at the time of weaning, i.e. the level of the zero-time control group. However, the extent to which immune competence developed as the animals matured was influenced by the type of plant oil consumed, and this influence was independent of the dietary oil level over a broad range. At the same time, increasing dietary oil level depressed humoral competence independently of oil type, but exerted no influence on cell-mediated competence. Importantly, these outcomes were independent of the gender of the animals and were obtained within the context of an investigation in which all plant oils and dietary oil levels supported comparable growth rates, including accretion of fat and lean tissue, that were appropriate for the age and strain of mouse used (Poiley, 1972; Woods \& Woodward, 1991; Woodward et al. 1995). Moreover, the work was done using cold-pressed oils, thereby eliminating the confounding influence of conventional refining procedures on oils susceptible to oxidative damage. A simple interpretation of the results is that, from the standpoint of the ability of a plant oil to support development of both cell-mediated and antibody-producing competence, an 18:2n-6 content not exceeding that of olive oil $(20 \mathrm{~g} / 100 \mathrm{~g}$ fatty acids $)$ is desirable, whereas the content of $18: 1 n-9$ and $18: 3 n-3$ is of little importance.

Antibodies impute defence against organisms occupying the extracellular space, whereas cell-mediated responses defend against intracellular infections as well as against tumour cells. Most acquired immune responses are subject to at least some level of cytokine-mediated $\mathrm{T}$ lymphocyte control. In particular, interferon- $\gamma$ promotes cell-mediated responses whereas interleukin 4, with or without the participation of interferon- $\gamma$, promotes the antibody type of response (Kuby, 1997). The anti-SRBC antibody response used in this investigation is dependent on $\mathrm{T}$ lymphocyte help (DeFranco, 1999), and both interferon- $\gamma$ and 'B-cell growth factor' (interleukin 4) appear to be needed (Leibson et al. 1984). In contrast, the anti-DNCB allergic contact dermatitis response is effected by $\mathrm{CD}^{+} \mathrm{T}$ lymphocytes, subject to regulation by the $\mathrm{CD}^{+}$subset, and is promoted by interferon- $\gamma$ (Dearman et al. 1996). The immune 
Table 5. Outcomes of correlation analysis relating the $18: 1 n-9,18: 2 n-6$ and $18: 3 n-3$ contents in the dietary oils with immune competence measures* $\dagger$

(Pearson's correlation coefficients)

\begin{tabular}{lcc}
\hline Fatty acid index & Anti-DNCB response & Anti-SRBC titre \\
\hline $18: 1 n-9$ level & $\mathrm{NS}$ & $\mathrm{NS}$ \\
$18: 2 n-6$ level & $-0.26(P=0.0001)$ & $-0.22(P=0.0001)$ \\
$18: 3 n-3$ level & $0.16(P=0.005)$ & $\mathrm{NS}$ \\
$18: 3 n-3: 18: 2 n-6$ ratio & $0.20(P=0.0004)$ & $\mathrm{NS}$ \\
$18: 1 n-9: 18: 2 n-6$ ratio & $0.27(P=0.0001)$ & $0.14(P=0.02)$ \\
$(18: 1 n-9+18: 3 n-3): 18: 2 n-6$ ratio & $0.29(P=0.0001)$ & NS
\end{tabular}

DNCB, dinitrochlorobenzene; SRBC, sheep red blood cell.

${ }^{*}$ For details of diets and procedures, see Tables 1 and 2 and p. 172.

$\dagger$ The analysis was conducted without consideration for dietary oil level or type.

responses used in the present investigation, therefore, represent the two types of acquired defence functions designed to confer protection against infectious agents, whether intracellular or extracellular, and involve the major lymphocyte subsets and cytokine regulatory activities. It is also relevant that the SRBC displays members of an antigen family, at one time known as Forssman antigens, likewise exhibited by many common bacteria including opportunistic pathogens (Sell, 1980).

Safflower oil provides a convenient point of reference for the purpose of interpreting the results of the present investigation because this oil is a rich source of $18: 2 n-6$ but contains low levels of the other two fatty acids that were the focus of this work, namely $18: 1 n-9$ and $18: 3 n$ 3 . Two outcomes emerge when the results are viewed in this way. First, only flaxseed oil supported development of more vigorous cell-mediated immune responsiveness than safflower oil, although animals fed diets formulated with rapeseed and olive oils did not differ in cell-mediated competence from animals consuming flaxseed oil. Second, flaxseed, rapeseed, olive and soyabean oils supported development of more vigorous antibody-producing capability than safflower oil. Consequently, it may be concluded that, among the oils examined in the present investigation, the order of potency in supporting development of acquired immune competence is as follows: flaxseed $=$ rapeseed $=$ olive $>$ soyabean $>$ maize $=$ safflower . This conclusion is independent of dietary oil level over the reasonably broad range included in the present investigation.

A small body of previous work pertains to flaxseed oil which has appeared depressive of cell-mediated immune competence relative to $n$-6-rich oils in some studies (Fritsche et al. 1991; Jeffery et al. 1996), but either was not different from $n$-6-rich oils in this respect (Marshall \& Johnston, 1985) or was stimulatory (Kelley et al. 1988; Fritsche \& Johnston, 1990) in other studies. The inconsistencies among studies do not appear related to the indices used to assess immune competence, but may relate to oil quality. Flaxseed oil is exceptionally susceptible to oxidation, and predictable product quality depends on application of strictly controlled cold-press conditions as well as on subsequent packaging and storage (Kolodziejczyk \& Fedec, 1995). A recent analysis conducted through the Birmingham City Laboratories suggests that the Omegaflo ${ }^{\circledR}$ (Omega Nutrition Canada Inc.) procedure is superior in minimizing oxidative damage and promoting shelf-life of cold-pressed flaxseed oil (Anonymous, 1999). Therefore, it is reasonable to suggest that a product equivalent in quality to the oil used in the present investigation is to be preferred in studies of dietary flaxseed oil. Moreover, the identity of a dietary oil is important to specify in reports of experimental work. Without this information, confident comparisons among studies cannot be made, a significant problem with the interpretation of existing literature relating to dietary flaxseed oil.

Consideration must also be given to previous studies of rapeseed and olive oil. Prior to the present investigation, no evidence was available that either of these plant oils might be superior to $n$-6-rich oils in promoting indices of immune competence. Thus, no difference was apparent between rapeseed and maize oils in supporting development of humoral and cell-mediated competence in the chick (Fritsche et al. 1991). In addition, an insightful analysis of a larger literature pertaining to olive oil concluded that, in contrast with the present results, olive oil is generally immune depressive relative to $n$-6-rich oils (Calder, 1998), although differences are not always apparent (Sanderson et al. 1995b). Previous information relating acquired immune competence to the consumption of either rapeseed or olive oils derives from studies of the refined products. Moreover, studies pertaining to olive oil have been based on use of the in vitro blastogenesis assay (Calder, 1998). Overall, therefore, attention to oilquality factors and emphasis on assessment of immune competence by means of in vivo indices may alter our understanding of the relative capacities of $n$-6-rich and $n$-6-poor plant oils to support the development of acquired immune competence in the young.

Correlation analysis revealed a negative association, independent of dietary oil type or level, between intake of $18: 2 n-6$ and the indices used to assess development of humoral and cell-mediated immune competence in the present investigation. This outcome is consistent with a large information base pertaining to indices of cellmediated immunity both in vitro and in vivo (Calder, 1998, 2001), and the finding also extends a narrowlybased literature that hints at the same relationship with regard to the antibody response (Calder, 2001). Further, a negative correlation with development of immune competence was seen only in the case of $18: 2 n-6$, in the present investigation, and all other significant correlations were 
positive. Considered together with the order of immunesupportive potency that emerged among the six oils in the present investigation, this outcome suggests that a key distinction among these oils in terms of their capacity to support development of acquired immune competence lies in their content of $18: 2 n-6$, which should not exceed the level found in olive oil, i.e. approximately $20 \mathrm{~g} / 100 \mathrm{~g}$ fatty acids. In this connection, it is noteworthy that olive and flaxseed oils (both of which have a low $18: 2 n-6$ content) supported comparable, high levels of immune competence despite their converse compositions with regard to $18: 1 n-9$ and $18: 3 n-3$ and despite the negligible quantity of $18: 3 n-3$ in olive oil. Collectively, the results point to a model in which $18: 1 n-9$ or $18: 3 n-3$ promote immunological development in the young indirectly through replacement of $18: 2 n-6$. In turn, the influence of such a replacement could be mediated, in part, through a shift in eicosanoid metabolism to reduce synthesis of prostaglandin $\mathrm{E}_{2}$ which, as discussed elsewhere (Beharka et al. 1997), suppresses numerous functions associated with acquired immune competence. This model is consistent with a recent report that macrophages from rats fed either olive oil or fish oil $(50 \mathrm{~g} / \mathrm{kg}$ diet from weaning through young adulthood) exhibited reduced capacity for synthesis of prostaglandin $E_{2}$ relative to macrophages from rats fed corn oil (Moreno et al. 2001).

Although statistically significant associations emerged in the present investigation between the fatty acid content of dietary oils and indices of acquired immune competence, the correlation coefficients were small. Discussions provided elsewhere (Calder, 1998, 2001) can be interpreted to suggest that the fatty acids examined here are the main immunologically active components of the saponifiable fraction of plant oils. Consequently, the differences identified among the six plant oils of the present investigation are likely to reflect compositional features in addition to fatty acids, and this deduction points to the non-saponifiable fraction. In this context, it is important to note that cold-pressed oils were used in the present investigation, and that extraction by cold-pressing preserves non-saponifiable components (Litridou et al. 1997) that are lost through conventional refining processes (Uceda \& Hermoso, 1997). The non-saponifiable fraction contains quantitatively minor compounds that are reported to promote acquired immune competence (Bouic et al. 1997). Thus, in the present investigation, eliminating the confounding factor of refinement may have introduced an interpretive complication relating to minor non-saponifiable components. These considerations further underscore the extent to which the present investigation represents a departure from previous literature based on the use of refined oils. A direct comparison between cold-pressed and fully refined oils is warranted regarding their capacities to support development of acquired immune competence.

A large body of literature supports the opinion that cellmediated immune competence relates inversely to dietary fat level regardless of the chemical nature of the fat or of the index of immune competence assessed (Calder, 1998, 2001). The results of the present investigation appear inconsistent with this generalization, but cell-mediated immune depression can be indiscernible in diet series that fail to include a sufficiently high level of fat. Studies of human subjects (e.g. Kelley et al. 1992) are easily and reasonably interpreted in this way. Moreover, in studies of rodents, fat levels of $200 \mathrm{~g} / \mathrm{kg}$ diet may be required to achieve discernible cell-mediated immune depression even where fish oil is the fat source (Hinds \& Sanders, 1993; Sanderson et al. 1995a), and even this high concentration, which exceeds the upper level included in the present investigation, can be insufficient to exert a discernible impact in the case of other types of fats including safflower and olive oils (Sanderson et al. 1995a).

The present investigation points to an inverse relationship between dietary fat level and humoral competence. This relationship was independent of dietary fat type within the diverse group of plant oils examined herein, and the phenomenon appears similar to that which is widely recognized (Calder, 1998, 2001) for cell-mediated immunity. Existing literature on this subject is narrowlybased and equivocal. For example, in studies of the mouse, the primary antibody response to the SRBC was unaffected by dietary maize oil levels supplying up to $70 \%$ dietary energy (DeWille et al. 1979) and this, as well as other, primary antibody responses was likewise unaffected by a dietary safflower oil content of $200 \mathrm{~g} / \mathrm{kg}$ (Crevel et al. 1992). In contrast $200 \mathrm{~g}$ safflower oil $/ \mathrm{kg}$ depressed the primary anti-SRBC antibody response of the mouse (Erickson et al. 1986), and both corn oil and tallow depressed the murine B cell blastogenesis response at this dietary level (Ossman et al. 1980). Where depression in the antibody response has been reported as a function of dietary fat level (Erickson et al. 1986; present investigation), the magnitude of the relationship was modest. In turn, this suggests a need for large studies in pursuing the phenomenon. The present investigation provides the first pertinent data set based on relatively large numbers of animals and diverse oil sources. It will be important to pursue this issue by studying species other than the mouse, by expanding the repertoire of antibody responses examined and by systematically increasing the diversity of oil sources compared while giving careful attention to the products investigated.

Although the $n-3$ fatty acid requirement of the mouse has not been defined quantitatively (National Research Council, 1995), the relatively inferior immunological performance supported by safflower and maize oils in the present investigation could be interpreted as a reflection of $n-3$ essential fatty acid deficiency, i.e. a function of the low levels of $18: 3 n-3$ in these oils coupled with their $18: 2 n$ $6: 18: n-3$ ratios. The results pertaining to olive oil, however, show that this is unlikely. Thus, despite the low concentration of $18: 3 n-3$ in olive oil (a level comparable with that of maize oil), this fat source was superior to soyabean oil in supporting the development of cell-mediated immune competence and was indistinguishable from flaxseed and rapeseed oils in supporting the development of both types of acquired immune response examined. These considerations further underscore the conclusion that dietary $18: 3 n-3$ fatty acid intake per se is of little consequence to the development of acquired immune competence in the young. In fact, a dietary source of $n-3$ fatty acids appears unnecessary for the development of this physiological 
capability. Further to this point, Robinson \& Field (1998) recently pointed out that an optimum dietary $n-6: n-3$ ratio has not been defined on the basis of immune competence. The results of the present investigation suggest that acquired immune responses are not useful for this purpose if the major portion of dietary $n-3$ fatty acids takes the form of $18: 3 n-3$.

An intervention that increases an antibody and/or cellmediated immune response is not, ipso facto, beneficial. First, an increased risk of either allergic or autoimmune disease could accrue. Such pathologies, however, are best understood as representing immune dysregulation in which humoral and cell-mediated responses are out of balance (Kuby, 1997). In contrast, low $n-6$ plant oils increased the rate of development of both types of acquired immune competence in a coordinated manner in the present investigation. Moreover, the magnitude of influence found in the present study was modest. Second, benefits in terms of resistance to infectious disease remain to be demonstrated in this experimental system. Such benefits are reasonable to anticipate, however, and the results reported here provide justification for initiating studies that impose infectious pathologies on animals.

Finally, both $18: 3 n-3$ and $18: 1 n-9$ are widely promoted for their cardiovascular benefits (Kris-Etherton, 1999; Bemelmans et al. 2002). Moreover, plant oil sources of these fatty acids, e.g. flaxseed (Nelson \& Chamberlain, 1995), rapeseed (Bierenbaum et al. 1991; de Lorgeril et al. 1994) and olive (Kris-Etherton et al. 1999; Larsen et al. 1999) oils exert a positive impact on cardiovascular risk factors in man. Thus, plant oils containing relatively low concentrations of $18: 2 n-6$, and concomitantly higher levels of $18: 1 n-9$ and/or $18: 3 n-3$, may emerge as health-promoting food choices on the basis of both cardiovascular benefits and capacity to reduce the risk of opportunistic infection.

\section{Acknowledgements}

This work was supported by the Ontario Ministry of Agriculture, Food and Rural Affairs, by the Ontario Soybean Growers' Marketing Board and by Omega Nutrition Canada Inc. (Vancouver, BC).

\section{References}

Anonymous (1999) Fat and fresh: The best linseed oil. Proof! What Works in Alternative Medicine 10, 11-13.

Beharka AA, Wu D, Han SN \& Meydani SN (1997) Macrophage prostaglandin production contributes to the age-associated decrease in $\mathrm{T}$ cell function which is reversed by the dietary antioxidant vitamin E. Mechanisms of Ageing and Development 93, 59-77.

Bemelmans WJE, Broer J, Feskens EJM, Smit AJ, Muskiet FAJ, Lefrandt JD, Bom VJJ, May JF \& Meyboom-de Jong B (2002) Effect of an increased intake of $\alpha$-linolenic acid and group nutritional education on cardiovascular risk factors: the Mediterranean Alpha-linolenic Enriched Groningen Dietary Intervention (MARGARIN) study. American Journal of Clinical Nutrition 75, 221-227.

Bhatty RS (1995) Nutrient composition of whole flaxseed and flaxseed meal. In Flaxseed in Human Nutrition, pp. 22-42 [SC Cunnane and LU Thompson, editors]. Champaign, IL: AOCS Press.

Bierenbaum ML, Reichstein RP, Watkins TR, Maginnis WP \& Geller M (1991) Effects of canola oil on serum lipids in humans. Journal of the American College of Nutrition 10, 228-233.

Bouic PJD, Etsebeth S, Liebenberg RW, Albrecht CF, Pegel K \& van Jaarsveld PP (1997) Beta-sitosterol and beta-sitosterol glucoside stimulate human peripheral blood lymphocyte proliferation: Implications for their use as an immunomodulatory vitamin combination. International Journal of Immunopharmacology 18, 693-700.

Calder PC (1998) Dietary fatty acids and the immune system. Nutrition Reviews 56, S70-S83.

Calder PC (2001) The effect of dietary fatty acids on the immune response and susceptibility to infection. In Nutrition, Immunity, and Infection in Infants and Children, pp. 137-168 [RM Suskind and K Tontisirin, editors]. Philadelphia, PA: Vevey/ Lippincott Williams \& Wilkins.

Corsini AC, Bellucci SB \& Costa MG (1979) A simple method of evaluating delayed type hypersensitivity in mice. Journal of Immunological Methods 30, 195-200.

Crevel RWR, Friend JV, Goodwin BFJ \& Parish WE (1992) High-fat diets and the immune response of C57 B1 mice. British Journal of Nutrition 67, 17-26.

Dearman RJ, Moussavi A, Kemeny DM \& Kimber I (1996) Contribution of $\mathrm{CD}^{+}$and $\mathrm{CD}^{+} \mathrm{T}$ lymphocyte subsets to the cytokine secretion patterns induced in mice during sensitization to contact and respiratory chemical allergens. Immunology $\mathbf{8 9}$, $502-510$

DeFranco AL (1999) B lymphocyte activation. In Fundamental Immunology, 4th ed., pp. 225-261 [WE Paul, editor]. Philadelphia, PA, New York, NY: Lippincott-Raven.

de Lorgeril M, Renaud S, Mamelle N, Salen P, Martin JL, Monjaud I, Guidollet J, Touboul P \& Delaye J (1994) Mediterranean alpha-linolenic acid-rich diet in secondary prevention of coronary heart disease. Lancet 343, 1454-1459.

DeWille JW, Fraker PJ \& Romsos DR (1979) Effects of essential fatty acid deficiency and various levels of dietary polyunsaturated fatty acids on humoral immunity in mice. Journal of Nutrition 109, 1018-1022.

Erickson KL, Adams DA \& Scibienski RJ (1986) Dietary fatty acid modulation of murine B-cell responsiveness. Journal of Nutrition 116, 1830-1840.

Fritsche KL, Cassity NA \& Huang SC (1991) Effect of dietary fat source on antibody production and lymphocyte proliferation in chickens. Poultry Science 70, 611-617.

Fritsche KL \& Johnston PV (1990) Effect of dietary omega-3 fatty acids on cell-mediated cytotoxic activity in BALB/C mice. Nutrition Research 10, 577-588.

Hinds A \& Sanders TAB (1993) The effect of increasing levels of dietary fish oil rich in eicosapentaenoic acid and docosahexaenoic acids on lymphocyte phospholipid fatty acid composition and cell-mediated immunity in the mouse. British Journal of Nutrition 69, 423-429.

Holub BJ \& Skeaff CM (1987) Nutritional regulation of cellular phosphatidylinositol. Methods in Enzymology 141, 234-244.

Hosack-Fowler K, Chapkin RS \& McMurray DN (1993) Effects of purified dietary $n-3$ ethyl esters on murine T lymphocyte function. Journal of Immunology 151, 5186-5197.

Jeffery NM, Sanderson P, Sherrington EJ, Newsholme EA \& Calder PC (1996) The ratio of $n-6$ to $n-3$ polyunsaturated fatty acids in the rat diet alters serum lipid levels and lymphocyte functions. Lipids 31, 737-745.

Kelley DS, Dougherty RM, Branch LB, Taylor PC \& Iacono JM (1992) Concentration of dietary $n-6$ polyunsaturated fatty acids 
and human immune status. Clinical Immunology and Immunopathology 62, 240-244.

Kelley DS, Nelson GJ, Serrato CM, Schmidt PC \& Branch LB (1988) Effect of type of dietary fat on indices of immune status of rabbits. Journal of Nutrition 118, 1376-1384.

Kolodziejczyk PP \& Fedec P (1995) Processing flaxseed for human consumption. In Flaxseed in Human Nutrition, pp. 261-280 [SC Cunnane and LU Thompson, editors]. Champaign, IL: AOCS Press.

Kris-Etherton PM (1999) AHA science advisory: Monounsaturated fatty acids and risk of cardiovascular disease. Journal of Nutrition 129, 2280-2284.

Kris-Etherton PM, Pearson TA, Wan Y, Hargrove RL, Moriarty K, Fishell V \& Etherton TD (1999) High-monounsaturated fatty acid diets lower both plasma cholesterol and triacylglycerol concentrations. American Journal of Clinical Nutrition 70, 1009-1015.

Kuby J (1997) Immunology, 3rd ed., New York, NY: WH Freeman and Company.

Larsen LF, Jespersen J \& Marckmann P (1999) Are olive oil diets anti-thrombotic? Diets enriched with olive, rapeseed, or sunflower oil affect postprandial factor VII differently. American Journal of Clinical Nutrition 70, 976-982.

Leibson HJ, Gefter M, Zlotnik A, Marrack P \& Kappler JW (1984) Role of $\gamma$-interferon in antibody-producing responses. Nature 309, 799-801.

Litridou M, Linssen J, Schols H, Bergmans M, Pstrhumus M, Tsimdou M \& Boskou D (1997) Phenolic compounds in virgin olive oils: fractionation by solid-phase extraction and antioxidant activity assessment. Journal of the Science of Food and Agriculture 74, 169-174.

Marshall LA \& Johnston PV (1985) The influence of dietary essential fatty acids on rat immunocompetent cell prostaglandin synthesis and mitogen-induced blastogenesis. Journal of Nutrition 115, 1572-1580.

Moreno JJ, Carbonell T, Sanchez T, Miret S \& Mitjavila MT (2001) Olive oil decreases both oxidative stress and the production of arachidonic acid metabolites by the prostaglandin $\mathrm{G} / \mathrm{H}$ synthase pathway in rat macrophages. Journal of Nutrition 131, 2145-2149.

National Research Council (1995) Nutrient requirements of the mouse. In Nutrient Requirements of Laboratory Animals, pp. 80-102. Washington, DC: National Academy Press.

Nelson GJ \& Chamberlain JG (1995) The effect of dietary $\alpha$-linolenic acid on blood lipids and lipoproteins in humans. In
Flaxseed in Human Nutrition, pp. 187-206 [SC Cunnane and LU Thompson, editors]. Champaign, IL: AOCS Press.

Ossmann JB, Erickson KL \& Canolty NL (1980) Effects of saturation and concentration of dietary fats on lymphocyte transformation in mice. Nutrition Reports International 22, 279-284.

Poiley SM (1972) Growth tables for 66 strains and stocks of laboratory animals. Laboratory Animal Science 22, 759-799.

Reeves PG, Nielsen FH \& Gahey GC Jr (1993) AIN-93 purified diets of laboratory rodents: final report of the American Institute of Nutrition Ad Hoc Writing Committee on the reformation of the AIN-76 rodent diet. Journal of Nutrition 123, 1939-1951.

Robinson LE \& Field CJ (1998) Dietary long-chain (n-3) fatty acids facilitate immune cell activation in sedentary, but not exercise-trained rats. Journal of Nutrition 128, 498-504.

Sanderson P, Yaqoob P \& Calder PC (1995a) Effects of dietary lipid manipulation upon graft vs host and host vs graft responses in the rat. Cellular Immunololgy 164, 240-247.

Sanderson P, Yaqoob P \& Calder PC (1995b) Effects of dietary lipid manipulation upon rat spleen lymphocyte functions and the expression of lymphocyte surface molecules. Journal of Nutritional and Environmental Medicine 5, 119-132.

Sell S (1980) Cytotoxic or cytolytic reactions. In Immunology Immunopathology and Immunity, 3rd ed., pp. 226-241 New York, NY: Harper \& Row.

Shipp K \& Woodward BD (1998) A simple exsanguination method that minimizes acute pre-anesthesia stress in the mouse: Evidence based on serum corticosterone concentrations. Contemporary Topics in Laboratory Animal Science 37, 73-77.

Shukla VKS (1994) Present and future outlook of the world fats and oils supplies. In Technological Advances in Improved and Alternative Sources of Lipids, pp. 1-15 [BS Kamel and Y Kakuda, editors]. New York, NY: Blackie Academic and Professional.

Uceda M \& Hermoso M (1997) La calidad del aceite de oliva. In El Cultivo del Olivo (Cultivation of the Olive), pp. 539-564 [D Barranco, R Fernandez-Escobar and L Rallo, editors]. Madrid: Junta de Andalucia \& Ediciones Mundeprensa.

Woods JW \& Woodward BD (1991) Enhancement of primary systemic acquired immunity by exogenous triiodothyronine in wasted, protein-energy malnourished weanling mice. Journal of Nutrition 121, 1425-1432.

Woodward BD, Bezanson KD, Hillyer LM \& Lee W-H (1995) The CD45RA ${ }^{+}$(quiescent) cellular phenotype is overabundant relative to the CD45RA ${ }^{-}$phenotype within the involuted splenic T cell population of weanling mice subjected to wasting proteinenergy malnutrition. Journal of Nutrition 125, 2471-2482. 